\title{
The importance of service quality in British Muslim's choice of an Islamic or non-Islamic bank account
}

\begin{abstract}
Using an extended SERVQUAL model, this study identifies and compares the importance of service quality to Muslim consumers with an Islamic or non-Islamic bank account in a non-Muslim country, Britain. Eight group discussions and survey with 300 Muslims were conducted. Five dimensions of service quality were identified, i.e. Responsiveness, Credibility, Islamic Tangibles, Accessibility and Reputation. These differ in structure and content from the original SERVQUAL developed in the west and the subsequent CARTER model constructed in a Muslim country. In addition, significant differences were found in the importance rating of items by respondents holding an account with an Islamic bank compared to those with a non-Islamic bank account. This study is one of the first to identify and compare the importance of service quality between Islamic and non-Islamic bank account holders in a western non-Muslim country. The results advance our understanding of the impact of culture on SERVQUAL. The study provides insight into Muslims' bank choice and helps bank managers of both Islamic and non-Islamic banks to focus their attention on the service quality dimensions that matter most to Muslim customers.
\end{abstract}

Key words. SERVQUAL, CARTER, Service quality, Islamic Banking, British Muslims, 


\section{The importance of service quality in British Muslim's choice of an Islamic or non-Islamic bank account}

\section{Introduction}

The global Islamic banking market is estimated to be worth $\$ 920$ billion and projected to grow to more than $\$ 1.6$ trillion by 2020 (EY, 2016). This rapid growth is due to demand from a large and growing Muslim population which is anticipated to make up more than a quarter of the global population by 2030 (Pew Forum, 2015); and to changes in national banking systems that have facilitated a growth in the supply of Islamic products as new providers enter the market (for an overview see Rammal, 2015)

To-date there have been numerous studies seeking to identify the SERVQUAL items used by consumers to evaluate their bank. Extant studies focusing on Islamic banks have found support for the importance of items similar to those in SERVQUAL, but have also included religion and compliance with Shariah, i.e., Islamic law (see for example, Saqib et al, 2016; Thaker et al, 2016; and Othman and Owen 2001). Studies have however been inconclusive, particularly for the inclusion of religion with some finding support for religion (Rehman, 2012; Al-Ajmi, Hussain and Al-Saleh 2009) and others finding little or no support (Ali and Raza, 2015; Erol and El-Bdour, 1989; Erol, Kaynek, El-Bdour, 1990). In addition, almost all studies have been conducted in eastern and predominantly Muslim countries (Saqib et al, 2016; Thaker et al, 2016; and Othman and Owen 2001; Metawa, 1998; Naser, Jamal and Al-Khatib, 1999; Dusuki and Abdullah, 2007). 
It is well established that culture and nationality have an impact on SERVQUAL (Nguyen et al, 2015), indeed one of the major criticisms of SERVQUAL is the need to take account of different contexts (Cronin and Taylor, 1992; Buttle, 1996). It is therefore not surprising that studies have repeatedly found customers to have different views on SERVQUAL based on their culture and nationality (see for example, Wongrukmit \& Thawesaengskulthai, 2014). Such differences are however also likely to occur due to acculturation, for example, where consumers move from their home country to take residence in another host country, or those who are first or second generation immigrants, as they hold onto their culture of origin or choose to assimilate with their new culture (Appostolova-Blossom, 1999). However, as Sekhon (2015) observes, decision making in such circumstances is not likely to be neatly categorised as there will be a blurring of the boundaries between home and host country. The take up of Islamic banking in Britain has been slow and disappointing (Griffiths, 2010). Reasons for the failure have been speculated, however empirical research is required to establish the basis on which British Muslims evaluate the service quality of their banks. It is therefore of both theoretical and practical interest to understand how British Muslims view service quality and its impact on their consumption choices.

Using an extended SERVQUAL model, this paper aims to identify and compare the importance of the SERVQUAL items used by British Muslims living in a nonMuslim country when evaluating the service quality of their Islamic or non-Islamic bank. The research questions are: what items and dimensions are important to British Muslims when evaluating the service quality of their bank; and what differences exist between the service quality perceptions of Muslims with Islamic bank accounts and those with non-Islamic bank accounts. 
This paper is structured as follows: first, the background to Islamic banking in the UK is presented, this is followed by a discussion of the theories that provide the foundation to this study. The methodology is then outlined, followed by the empirical findings, discussion and conclusion. The paper concludes with its contribution, limitations of the study, future research and implications for practice.

\section{Background to Islamic Banking in the UK}

The UK has a strong Muslim presence, accounting for 2.7 million or $4.5 \%$ of the UK population (ONS, 2011). This is the largest ethnic minority in the UK. Muslims are excellent prospects for banking and financial products with an estimated 10,000 Muslim millionaires (Travus, 2009), total savings of $£ 1$ billion and approximately $25 \%$ having annual incomes of over $£ 30,000$ (Matthews, Tlemsani and Siddiqui, 2003).

Islamic banks perform the same essential functions as non-Islamic banks, except they carry out their transactions according to the principles of Islamic (Shariah) law. Shariah forbids interest, therefore Islamic financial institutions use a number of financing techniques to derive returns for their customers based on transactions associated with tangible assets (for more detail on how Islamic banks work see Rammal, 2015). Britain has the most developed Islamic financial services sector in the western world (Mair and Khan, 2015). Islamic banks first entered the UK in the 1980s (Cunningham, 1996) with the Al Baraka International Bank being an early pioneer. Others have since followed, for example, the United Bank of Kuwait and Al Ahli United Bank, the UK based Europe Islamic Investment Bank and the Qatar Islamic Bank. The UK is home to the first wholly Shariah compliant retail bank in the 
west, Al Rayan (formerly the Islamic Bank of Britain), which was authorized by the FSA in 2004 (FSA, 2006). The UK banking sector is highly competitive and all banks (both non-Islamic and Islamic) need to know how to attract and retain customers.

\section{Service Quality, Banks and Islamic Banks}

Service quality is viewed as an important issue for businesses due to its apparent relationship with customer satisfaction (Bolton and Drew, 1991), customer retention (Reichheld and Sasser, 1990) and profitability (Rust and Zahorik, 1993). Businesses that manage their service quality well are therefore more likely to be successful businesses.

Most previous research on service quality has used the SERVQUAL instrument, developed by Parasuraman et al (1985) and constructed of 22 items forming originally 10 dimensions which were subsequently reduced to 5. SERVQUAL has been applied to a wide range of service industries, including financial services. Despite its widespread use (Ladhari, 2012), SERVQUAL has been criticised. Many researchers (e.g. Nugyen et al, 2016; Carrillat, Jaramillo and Mulki, 2007; Buttle, 1996; and Cronin and Taylor, 1992) suggest that service quality cannot be applied universally, the effect of a consumer's culture and context need to be considered. Indeed, Lapierre (1996) concluded that the search for a universal conceptualization of service quality may be futile and that service quality needs to be measured and described in the language of those providing the data. In addition, Malhotra et al (2005) suggest that other factors, such as whether or not a customer lives in a developed or developing country, can influence the SERVQUAL dimensions. These authors all highlight the need to develop SERVQUAL for each context, by industry, by culture or both. 
Historically, service quality has been viewed as an important issue in the banking industry (Stafford, 1994). Indeed, service quality is considered the primary factor in customer satisfaction with banks due to its impact on customer loyalty (Gait and Worthington, 2008). Perhaps as a direct result there has been a wide range of studies that have examined SERVQUAL in a banking context (see for example, Avkiran 1994; Haque, 2010; Mersha and Adlaka, 1992). The majority of studies have measured service quality by replicating or adapting the SERVQUAL model (e.g. Ali and Raza, 2015; Bose and Gupta, 2013; Aldlaigan and Buttle, 2002). In almost all studies the items have been amended to reflect the banking context, for example price has been changed to include service charges (Javalgi et al, 1989) or interest on savings (Laroche et al, 1986). Others have adapted the measurement, for example, BANKSERV (Avkiran, 1999) is a single scale measurement of service quality where customers can reflect their perceptions and expectations in a single statement; and Ennew et al (1993) and Hemmasi et al (1994) used the importance-performance measure, which looks at how well a service attribute meets customer needs.

SERVQUAL has also frequently been used with Islamic banks to measure service quality. The CARTER model (Othman and Owen, 2001), was the first SERVQUAL based model to be developed for the Islamic banking industry. Notably, it has as a sixth dimension 'compliance with Islamic law' which includes items such as, run on Islamic law and principles, interest neither paid nor taken on savings and loans, provision of Islamic products and services, provision of free interest loans and provision of profit sharing investment products. Othman (2003) called for researchers to examine the model's validity and to measure overall service quality levels in the 
Islamic banking industry in different locations. Subsequent studies have tended to adopt this model but primarily for research conducted in Muslim countries (see for example, Shafie, Azmi and Haron, 2004; Ciptono and Soviyanti, 2007; Rehman, 2012).

The UK is a multi-cultural society and the Muslim population is a significant minority group (ONS, 2011). , Acculturation, i.e. the degree to which Muslims hold onto their home culture or choose to assimilate with their new host culture (AppostolovaBlossom, 1999), will potentially impact the service quality measure. Berry (1997) identified four acculturation possibilities. In the context of this study, assimilation would be where Muslim's do not wish to maintain their Islamic cultural identity and seek daily interaction with the host cultures; separation, would be where Muslims hold onto their original Islamic culture; Integration would be evidenced by the maintenance of some degree of Islamic integrity while also seeking to participate as an integral part of the larger social network and finally, marginalisation, would be where Muslims have little possibility or interest in cultural maintenance.

This study responds to Othman's call for the further development of a service quality measure for Islamic banking, but seeks to develop a modified SERVQUAL/CARTER model for Muslims in a non-Islamic country. The two research questions to be addressed are: what items and dimensions are important to British Muslims when evaluating the service quality of their bank; and, second, what differences exist between the service quality perceptions of Muslims with Islamic bank accounts and those with non-Islamic bank accounts.

\section{Methodology}


Data was collected by means of a classic two stage, mixed methods approach. In stage one, 8 group discussions were conducted with 36 Muslims to explore the relevance of a set of service quality items generated from the literature, generate new items and validate the descriptors and check the definitions of the words used. All groups were asked open questions to stimulate discussion, for example, what they liked/disliked about their bank, how they judge good/poor service? Group discussions were conducted in English, although Arabic (the moderator's mother tongue) was used when appropriate to help define words and aid understanding where appropriate.

Group discussion participants were predominantly aged between 20 and 40 years old (27 participants) and married (26). 22 of the participants were male and 14 were female. Most had lived in England for 10 or more years. The majority of participants were highly qualified, 12 held a bachelor degree and 11 a Masters, another 10 held college, high school or secondary school qualifications. The participants represented a mix of occupations and professions, for example, lawyers, doctors, administrators, police and included students and housewives.

The findings from stage one were used both to inform and direct the development of the items used in the stage two survey. Analysis of the groups identified support for 34 items which included items from the original SERVQUAL and CARTER models and new items that emerged from the 8 focus group discussions (see Table 2 for a listing). Support was found for 19 service items closely matching those appearing in SERVQUAL (the 3 that were not supported were: neat appearance of employees, visually appealing materials associated with service, and insisting on error free records). Support was also found for an additional 5 items specifically concerning bank service (e.g. bank location, confidentiality, service charges, etc.) typically found 
in bank service quality studies. In addition, a further 10 items linking directly to the Islamic nature of the bank were identified from the group discussions. 3 overlapped with the CARTER model (Othman and Owen, 2011), namely, run on Islamic principles, provision of Islamic products \& services, and provision of free interest loan. The additional new Islamic banking items to emerge from the groups included confidence in bank's Shariah advisors, female staff wear hijab, bank has a prayer room, closing for Friday prayer, and separate department for ladies. Together these items account for the 34 items used in the survey (see Table 2).

In stage two, a survey was used. A pilot was first conducted with 12 Muslims 7 nonIslamic bank account holders and 5 Islamic bank account holders) to test the questionnaire in terms of clarity, layout, length and completion time. All pilot respondents completed the questionnaire in the presence of the researcher. As a result of the pilot test, questionnaire phrases were simplified to aid understanding for those with English as a second language.

Questionnaires were then distributed by hand at places where Muslims congregate, for example, Islamic centres, Muslim community centres and, schools. To avoid any religious overtones and bias, questionnaires were also distributed at supermarkets, shops, restaurants, cafes, parks etc. A convenience sample was used, individuals were identified to take part in the survey if they confirmed that they were Muslim and lived in the UK. Data collection took place at locations known to have a high number of Muslims, i.e. London, West Midlands and the North West England (ONS, 2011). Questionnaires were handed to respondents for self-completion and the researcher 
waited to collect them. 350 completed questionnaires were received, however, only $300(86 \%)$ were suitable for analysis due to incomplete or missing data.

Respondents were asked to rate each of the 34 service quality items according to importance on a 5 point Likert scale. Questionnaires were analysed using SPSS. Exploratory factor analysis (Principal Components Analysis: PCA) was used to identify a smaller number of linear combinations of the original variables in a way that captures most of the variability in the pattern of corrections (Pallant, 2005; and Field, 2005). Table 2 depicts the results and identifies the items and factors used by Muslims when considering the importance of service quality for their bank. The Mann Whitney test was used to test for a significant difference between two samples that are independent and may be of different size (Curwen, and Slater, 2002). In this study, Mann-Whitney was used to test the differences between Islamic bank account holders and non-Islamic bank account holders' importance of the service quality items.

\section{Findings}

\section{Respondent Profile}

Respondents completing the survey included slightly more males (58\%) than females (42\%) with just over half (52\%) of respondents married. Age wise, $49 \%$ were aged up to 30 years old, $32 \%$ of the sample were between 31 and 40 , and $19 \%$ were aged between 41 and 51 years old. In terms of income, just under one third earned less than $£ 10,000$ p.a., just over one third earned between $£ 10,001$ and $£ 20,000$ and the over one third earned over $£ 20,000$. See Table 1 for a full details of respondent profile.

[insert Table 1 around here] 
$32 \%$ of respondents held Islamic banks accounts (85\% of which held an account with an Islamic bank and 15\% with a non-Islamic bank via an Islamic window) and $68 \%$ were non-Islamic bank account holders. Although the number of respondents with Islamic bank accounts was disappointing, this reflects the low take up of Islamic bank accounts in the UK (Griffiths, 2010) and is comparable to other studies (e.g. Kumar et al, 2010).

\section{Dimensions of Service Quality}

All 34 items loaded on 5 factors (the service quality dimensions) with eigenvalues exceeding 1 . The Kaiser-Meyer-Olkin (KMO) measure of sampling adequacy exceeds the recommended value of 0.6 (Pallant, 2005, Field, 2005) at 0.925 . This value suggests that the identified clusters are compact enough to ensure that the factor analysis will give distinct and acceptable factors, and the sample used was adequate. In addition, the Bartlett test was highly significant (sig. $=0.000$ ), which indicates that there are sufficient significant correlation coefficients to ensure that the factor analysis processes can be applied.

[Insert Table 2 around here]

Most of the service quality items loaded with correlation coefficients of more than 0.50 , and only two items (easy bank to deal with and bank reputation) loaded with correlation coefficients less than 0.50 ( 0.48 and 0.46 respectively). The 5 factors explain $16.48 \%, 15.96 \%, 11.57 \%, 10.96 \%$ and $10.08 \%$ of the variance respectively. 
Factor 1: Responsiveness. This factor is the strongest of the 5 dimensions, but by a small margin. It nevertheless represents the most important items that British Muslims want to see in their banks. This factor loaded on 9 items comprising a combination of items from the SERVQUAL dimensions responsiveness and empathy and the CARTER dimensions of assurance and responsiveness. This factor concerns the friendly, polite and knowledgeable nature of the bank employees; and the speed and efficiency of the service provided. In contrast to CARTER (Othman and Owen, 2001) which loaded first on Compliance, this factor does not include any reference to the Shariah requirements for an Islamic bank.

Factor 2: Credibility. This consists of 11 items and closely matches the original SERVQUAL dimensions of credibility and security and overlaps with the CARTER model on the dimensions of empathy and compliance with Shariah law. The Credibility factor includes items directly relating to the Islamic nature of the bank, for example, confidence in the bank's Shariah advisors and the bank running according to Islamic law. In addition, it also includes more general items; for example, secure banking, confidence in the bank's management and accurate statements. Credibility ranks a close second in terms of importance to Responsiveness. This supports the earlier work of Jabnoun and Al Tamini (2003) where similarities were also found between these two dimensions.

Factor 3: Islamic Tangibles. Previous researchers (Parasurman et al, 1991, Zeithaml and Bitner, 2003 and Jabnoun and Al Tamimi, 2003) defined tangibles as the appearance of physical facilities, equipment, personnel and communication materials. The CARTER model also included the external appearance of the bank and the 
opening hours (Othman, 2003). Islamic Tangibles loads on 5 items and the tangible evidence relates to the bank being seen as truly Islamic, e.g. female staff wearing hijab, providing a prayer room, a separate department for women and closing for Friday prayer time. Evidence from the earlier group discussions suggests that Islamic Tangibles are particularly important in a non-Muslim country to reassure customers that the bank is truly 'Islamic'.

Factor 4: Accessibility. Of the 5 items loading on this factor, 4 centre on the original SERVQUAL dimension of access. For example, the number of cash machines, convenient opening hours, wide range of services (e.g. financial advisor) and bank location. The CARTER model classified some of these items as tangibles, reflecting their physical nature. Notably, low service charge is also included in this dimension and perhaps reflects the notion that a high service charge would prevent customer use.

Factor 5: Reputation. This factor loads on 4 items: bank size, well known bank, Islamic architecture and modern looking equipment. 3 of the 4 items are similar to those in Factor 3, Islamic Tangibles, in that they refer to tangible evidence (the bank's size, buildings and equipment). As Reputation also loads on well-known bank this suggests that this factor is about the bank's overall reputation.

It is notable that in this study items relating to the Islamic nature of the bank appear in 4 of the 5 factors, however in CARTER, Islamic items load on just one factor, Compliance. This embeddedness of the Islamic items may reflect a desire for British Muslims to have greater reassurance about the Islamic nature of their bank at different touch-points. 
In this section, we identified the bank service quality dimensions as rated by British Muslims. In the next section, we explore how the rating of these dimensions differ between British Muslims choosing an Islamic and a non-Islamic bank.

\section{Bank Choice}

To test whether or not a relationship exists between respondents' rating of the items by importance and their bank (i.e., Islamic or non-Islamic) a Mann-Whitney nonparametric test was used. A significant difference was found to exist with respect to twelve items, which mainly belong to the Credibility and Responsiveness dimensions, as shown in Table 3

[Insert Table 3 about here]

If we compare the mean rankings of non-Islamic bank account holders with those of Islamic bank account holders it can be seen that the responses of the former exceed those of the later. This means that these items are more important to non-Islamic Bank account holders. In addition, if we compare the median values of each proposed item, the non-Islamic bank accountholder medians are either equal to or higher than the Islamic bank account holders. Thus, the non-Islamic bank account holders rate these items as being more important than the Islamic bank account holders.

The items that were rated as more important by non-Islamic bank holders relate to 3 of the dimensions identified in Table 2: Credibility, Responsiveness and Accessibility. The Credibility items rated higher by non-Islamic bank account holders concern 
secure banking, safety from political action, confidence in bank management, bank reputation and confidentiality of customer information. Themes to emerge from the group discussions provide insight into this finding. Respondents reflected on Islamic banks that had closed and western governments who had in the past frozen the bank accounts of Muslims. It would appear that in response to these concerns some British Muslims were choosing to bank with non-Islamic banks for credibility and, in particular, security reasons.

The Responsiveness items concern helpfulness, friendliness and the politeness of employees who can solve problems quickly. Non-Islamic bank account holders therefore place higher importance on the interaction with staff than their non-Islamic bank account holder counterparts. Customer service was considered important to these consumers. Finally, non-Islamic bank account holders place greater importance on Accessibility and in particular convenience as they rated the following items more important than their Islamic bank account holding counterparts: convenient bank location and convenient opening hours.

\section{Discussion and Conclusion}

This research identified 34 items and 5 dimensions that can be used to evaluate the service quality preferences of Muslim customers in Britain. The items loaded differently to those in the original SERVQUAL and CARTER models. Responsiveness, Accessibility and Reputation more closely resemble the original SERVQUAL instrument, whereas Credibility and Islamic Tangibles specifically concern Islamic based items. It is interesting to note that Responsiveness, is viewed as the most important factor (albeit marginally) for British Muslim customers whereas in 
the CARTER model, conducted in Kuwait, the Islamic or 'compliance' factors' loaded first. This study therefore reinforces the multi-dimensional nature of service quality (Othman and Owen, 2002) and the need to develop different service quality instruments for different contexts and cultures (Cronin and Taylor, 1992; Buttle, 1996).

In addition, the findings highlight the potential influence of acculturation on service quality preferences. British Muslims appear to demonstrate evidence of integration (Berry, 1997) through the higher rating of Responsiveness as important in service quality but retain Islamic items in most of the other dimensions. Those choosing to bank with a non-Islamic bank rated the service quality factors differently to those with an Islamic bank account. The choice of an Islamic account may be evidence of separation (Berry, 1997) and ground the individual in their Muslim identity as they hold on to their original Islamic culture.

In this study we considered British Muslims as one group, however, we have identified that British Muslims are not one homogenous group with respect to service quality and banking. Acculturation is a complex concept (Phinney, 2003) and this study has provided only a preliminary insight into this area. Further work is required to understand in more detail British Muslims' attitudes and acculturation strategies with respect to banking. Previous studies have tended to explore banking as a precursor to acculturation (Gail Perry, 2008); we call for further research to identify how acculturation can impact perceptions of service quality and banking behaviour. 
This study has implications for bank managers. All respondents rated items concerning employee skills as important and these featured prominently in the first dimension, Responsiveness. Those banking with non-Islamic banks rated these items as particularly important. Employees continue to play a significant role in bank customer interaction and Islamic banks are recommended to develop their employees to deliver a good and personal service to their customers and so increase customer satisfaction. This might be achieved through training and education programmes with a focus on Islamic law and its impact on banking products and how different products meet the requirements of Shariah law.

Accessibility was rated as more important by non-Islamic bank account holders. Islamic banks can take steps to address this by, for example, providing more cash machines, internet banking and expanding their branch network so that they are more visible in the market and create greater awareness of their presence. Participants in the group discussion suggested that Islamic banks could also achieve this by co-operating with other well-known banks, organisations, and large supermarkets thereby expanding their distribution. Group discussion participants also suggested that such links would also help Islamic banks to gain the trust of British Muslims as they are not highly visible in the UK when compared to the non-Islamic banks that have a branch on every high street.

The findings of this study highlighted the importance of Islamic Tangibles that would reinforce the Islamic nature of an Islamic bank. These include the visible cues of a separate department for females, a prayer room and female staff wearing hijab. Within the group discussions, participants also suggested that more information could be 
provided by Islamic banks on, for example, the background and expertise of those individuals who were their Shariah advisors. Previous studies (Ashraf, Robson and Sekhon, 2015) have suggested that customers of Islamic banks do not necessary have trust and confidence in the Islamic compliance of their bank and such measures will help to provide reassurance.

British non-Islamic banks already have a higher market share than their Islamic bank counterparts within the Muslim community. If they are continue to occupy this dominant position they need to highlight those features that appeal most to British Muslims, customer service, convenience and safety. The latter is perhaps the most challenging given the recent banking crisis. However, banks can communicate the measures that are in place to safeguard consumer accounts.

\section{Limitations and Future Research}

As with all studies, this research is not without its limitations and these form the basis of our suggestions for future research. First, this study was undertaken in Britain and the SERVQUAL instrument was developed for banks in this market. This scale may be applicable to Islamic banks in other European and/or western countries. However, caution is recommended as the UK Islamic banking sector is fairly mature when compared and contrasted to other western markets (Mair and Khan, 2015) and this difference in the economic environments and regulations needs to be taken into consideration (Othman, 2003). It is therefore recommended that the items are reexamined and potentially re-defined taking into account differences in each country's context and environment. 
Second, almost one third of the sample (32\%) in this study held an Islamic bank account. This is a relatively small number and reflects the market share of Islamic banks in the UK (Griffiths, 2010). Future studies should, however, try to address this issue and seek to obtain a higher number/proportion of Islamic bank account holders. This may be achieved by obtaining the support and co-operation of the Islamic banks to help distribute the questionnaires. Caution would however need to be exercised however when analysing the results which may be specific to the bank providing access.

Third, this study focused on Muslim customers, non-Muslim customers have not been included in this research. Islamic banks are increasingly being viewed as an ethical alternative to non-Islamic banks, positioned as 'participant' banks and therefore a choice for non-Muslims particularly given the negative press non-Islamic banks have received during the recent credit crisis and recession. What motivates non-Muslims to bank with an Islamic bank would be another interesting and topical question to investigate.

Finally, we alluded earlier to the need to undertake further detailed research into how acculturation impacts service quality. This study considered British Muslims as one group. We call for further research to identify how the different categories of acculturation (Berry, 1997) can impact perceptions of service quality and banking behaviour. 


\section{References}

Al-Ajmi, J., Abo Hussain, H. and Al-Saleh, N., (2009). Clients of conventional and Islamic banks in Bahrain: How they choose which bank to patronize. International Journal of Social Economics, 36(11), 1086-1112.

Aldlaigan, A.H. and Buttle, F.A. (2002). SYSTRA-SQ: a new measure of bank service quality. International Journal of Service Industry Management, 13(4), 362381.

Ali, M. and Raza, S.A. (2015). Service quality perception and customer satisfaction in Islamic banks of Pakistan: the modified SERVQUAL model. Total Quality Management \& Business Excellence, 1-19.

Apostolova-Blossom, E. (1999) Special session summary identity and modern consumption. In: B. Dubois, T.M., Lowery, L.J. Shrum \& M. Vanhuele (eds) European Advances in Consumer Research, 4. Provo, UT: Association for Consumer Research, pp. 332-335.

Ashraf, S., Robson, J., \& Sekhon, Y. (2015). Consumer trust and confidence in the compliance of Islamic banks. Journal of Financial Services Marketing, 20(2), 133 144.

Avkiran, K. (1999). Quality customer service demands human contact. International Journal of Bank Marketing. 17(2), 61-71

Berry, J. W. (1997). Immigration, acculturation, and adaptation. Applied psychology, 46(1), 5-34.

Bolton, R.N. and Drew, J.H. (1991) A multistage model of customers assessment of service quality and value. Journal of Consumer Research, 17(March), 375-384.

Bose, S., \& Gupta, N. (2013). Customer perception of services based on the SERVQUAL dimensions: A study of Indian commercial banks. Services Marketing Quarterly, 34(1), 49-66.

Buttle, F. (1996). SERVQUAL: review, critique, research agenda. European Journal of Marketing, 30(1), 8-32.

Carrillat, F.A., Jaramillo, F. and Mulki, J.P. (2007) The validity of the SERVQUAL and SERVPERF scales: A meta-analytic view of 17 years of research across five continents. International Journal of Service Industry Management, 18(5), 472-490.

Ciptono, W. and Soviyanti, E. (2007). Adapting Islamic Bank's Carter Model: An Empirical Study in Riau's Syariah Banks, Indonesia. Proceeding PESAT Auditorium Kampus Gunadarma, 2, 1858-2559. 
Cronin, J. and Taylor S. (1994). SERVPERF Versus SERVQUAL: Reconciling Performance - Based and Perceptions- Minus- Expectations Measurement of Service Quality. Journal of Marketing, 58(1)

Cronin, J. and Taylor, S. (1992). Measuring SQ: re-examination and extension. Journal of Marketing, 56, 55-68.

Cunningham, A. (1996). Banking in the middle east. London: FT Financial Publishing Dar, H. (2005). Demand for Islamic financial service in the UK: much ado about nothing. New Horizon, February, 11-12.

Curwin, J.and Slater, R., 2002. Quantitative Methods for Business Decisions. 5th ed. London: Thomson Learning.

Dusuki, W.A. and Irwani A, N. (2007) Why do Malaysian customers patronise Islamic banks?. International Journal of Bank Marketing, 25(3), 142-160.

Ennew, C.T., Reed, G.V. and Binks, M. R. (1993). Importance-performance analysis and the measurement of service quality. European Journal of Marketing, 27(2), 59 70 .

Erol, C. and El-Bdour, R. (1989). Attitudes, behaviour, and patronage factors of bank customers towards Islamic banks. International Journal of Bank Marketing, 7(6), 3137 .

Erol, C., Kaynak, E. and Radi, E.B. (1990). Conventional and Islamic banks: patronage behaviour of Jordanian customers. International Journal of Bank Marketing, 8(4), 25-35.

EY (2016). The world Islamic Banking competitiveness report. Ernest \& Young. Available from: ey.com. Accessed $16^{\text {th }}$ March 2017.

FSA (2006), March 2006, Islamic banking in the UK, a briefing. Financial Service Authority Note BN016/06, available online: http://www.fsa.gov.uk

Gail Perry, V. (2008). Acculturation, microculture and banking: An analysis of Hispanic consumers in the USA. Journal of Services Marketing, 22(6), 423-433.

Gait, A. and Worthington, A. (2008). An empirical survey of individual consumer, business firm and financial institution attitudes towards Islamic methods of finance. International Journal of Social Economics, 35(11), 783-808.

Griffiths, K (2010) Sharia-compliant banking products a 'huge-flop' in Britain. The Australian. http://www.theaustralian.com.au/business/industry-sectors/shariacompliant-banking-products-a-huge-flop-in-britain/story-e6frg96f-1225882133009. Accessed June 212010

Haque, A., Ahmed, K. and Irfath Jahan, S. (2010). Shariah observation: advertising practices of Bank Muamalat in Malaysia. Journal of Islamic Marketing, 1(1), 70-77. 
Haron, S. and Shafie, S. (2004). Adopting and Measuring Customer Service Quality (SQ) in Islamic Banks: A Case Study in Bank Islam Malaysia Berhad. Muamalat and Islamic Finance Research, 1(1), 91-102.

Hemmasi, M., Strong, K. and Taylor, S. (1994), Measuring service quality for planning and analysis in service firms, Journal of Applied Business Research, 10(4), 24-34.

Jabnoun, N. and Al-Tamimi, A.H. (2002) Measuring Perceived Service Quality at UAE Commercial Banks. International Journal of Quality and Reliability Management. 20(4), 458-472

Jabnoun, N. and Khalifa, A. (2005) A customized measure of service quality in the UAE. Managing Service Quality,.15(4), 374-388.

Javalgi, R.G., Armacost, R.L. and Hosseini, J.C. (1989). Using the analytic hierarchy process for bank management: Analysis of consumer bank selection decisions. Journal of Business Research, 19(1), 33-49.

Kemal Avkiran, N., 1994. Developing an instrument to measure customer service quality in branch banking. International Journal of Bank Marketing, 12(6), 10-18.

Ladhari, R. (2009), A review of twenty years of SERVQUAL research. International Journal of Quality and Service Sciences, 1(2), 172-19

Lapierre, J., Filiatrault, P. and Perrien, J. (1996). Research on service quality evaluation: evolution and methodological issues. Journal of Retailing and Consumer Services, 3(2), 91-98.

Laroche, M., Rosenblatt, J.A. and Manning, T. (1986). Services used and factors considered important in selecting a bank: an investigation across diverse demographic segments. International Journal of Bank Marketing, 4(1), 35-55.

Laroche, M., Ueltschy, L.C., Abe, S., Cleveland, M. and Yannopoulos, P.P. (2004). Service quality perceptions and customer satisfaction: evaluating the role of culture, Journal of International Marketing, 12(3), 58-85.

Mair, M and Khan, M (2015) Britain to lead the world in Islamic finance. Thursday 24 November 2016. The Telegraph.co.uk. Accessed 28.11.16 Available from http://www.telegraph.co.uk/finance/newsbysector/banksandfinance/11435465/Britainto-lead-the-world-in-Islamic-finance.html

Mathews, R, Tlemasni, I. and Siddiqui, A. (2002) Islamic Finance, Centre for International Business Policy, Kingston Business School, Surrey.

Malhotra, N. K., Ulgdo, F. M., Agrwal, J., Shainesh, G. and Wu, L. (2005). Dimensions of service quality in developed and developing economies: multi-country cross-cultural comparisons, International Marketing Review, 22(3), 256-278. 
Mersha, T. and Adlakha, V. (1992). Attributes of service quality: the consumers' perspective. International Journal of Service Industry Management, 3(3), 34-45.

Metawa, S.A. and Almossawi, M. (1998). Banking behavior of Islamic bank customers: perspectives and implications. International Journal of Bank Marketing, 16(7), 299-313.

Naser, K., Jamal, A. and Al-Khatib, K. (1999). Islamic banking: a study of customer satisfaction and preferences in Jordan. International Journal of Bank Marketing, 17(3), 135-151.

Nguyen, N., Cao, T. K. and Phan, T. T. (2015). Cultural Influences on Overall Service Quality Expectations: Evidence from Vietnamese Customers. Asian Social Science 11(25), 151-159

Okumuş, H.Ş. (2005) Interest-free banking in Turkey: a study of customer satisfaction and bank selection criteria. Journal of Economic Cooperation, 26(4), 51-86

Othman A. Q. and Owen L. (2001) Adopting and Measuring Customer Service Quality in Islamic Banks: A Case Study in Kuwait Finance House. International Journal of Islamic Financial Services, 3(1), 6-12.

Pallant, J. (2005). SPSS Survival Manual. 2nd ed, Sydney: Allen and Unwin. Field, A., 2005. Discovering statistics using SPSS. 2nd ed. London: Sage publications Ltd.

Parasuraman. A., Berry L. and Zeithmal V. (1985). A Conceptual Model of SQ and Its Implications for Future Research. Journal of Marketing, 49(3), 41-50.

Pew Forum (2015) The future of world religions: population growth projections, 2010-2050. Pew Research Centre. April $2^{\text {nd }}, 2015$. Available from www.pewforum.org/2015/04/02/religious-projections-2010-2050/

Phinney, J. S. (2003). Ethnic Identity and Acculturation. In (eds) K. M. Chun, P. Balls and G. Marin, Acculturation: Advances in Theory, Measurement and Applied Research. American Psychological Association, Washington DC, pp. 63-81.

Rammal, H (2015) Islamic Banking in (eds) T Harrison and H Estelami, Routledge Companion to Financial Services Marketing. Routledge, Oxon, England.

Rehman, A.A. (2012) Customer satisfaction and service quality in Islamic banking. Qualitative Research in Financial Markets. 4 (2/3) 165-175

Reichheld, F.F.; Sasser Jr., W. E. (1990) Harvard Business Review. 68(5), Sep/Oct 105-111.

Rust, R.T. and Zahorik, A. (1993). Customer satisfaction, customer retention and market share. Journal of Retailing, 69(2), 193-215 
Sekhon, Y.K. (2015). Ethnic consumer decision making. In (eds Jamal, A., Peñaloza, L. and Laroche, M.). The Routledge Companion to Ethnic Marketing. Routledge, pp 211-219.

Shafie, S., Azmi, W.N.W. and Haron, S. (2004). Adopting and measuring customer service quality in Islamic banks. Journal of Muamalat and Islamic Finance Research, $1(1), 1-12$.

Saqib, L., Saqib, L., Farooq, M.A., Farooq, M.A., Zafar, A.M. and Zafar, A.M., (2016). Customer perception regarding Sharī 'ah compliance of Islamic banking sector of Pakistan. Journal of Islamic Accounting and Business Research, 7(4), 282303.

Stafford, M (1994) How Customers Perceive SQ. Journal of Retail Banking, 17(2), 29-38

Thaker, H.M.T., Khaliq, A. and Thaker, M.A.M.T., (2016). Evaluating the service quality of Malaysian Islamic Banks: An importance-performance analysis approach. International Journal of Business and Information, 11(3), 341.

Travus, A. (2008) Officials think UK's Muslim population has risen to $2 \mathrm{~m}$. The Guardian, Tuesday 8 April 2008. Accessed 4.11.09

Wongrukmit, P. and Thawesaengskulthai, N. (2014). Hospital service quality preferences among culture diversity. Total Quality Management \& Business Excellence, 25(7-8), 908-922. 
Table 1. Respondent profile

\begin{tabular}{|c|c|c|}
\hline & Grouping & Percentage \\
\hline \multirow[t]{2}{*}{ Gender } & Male & 58.3 \\
\hline & Female & 41.7 \\
\hline \multirow[t]{4}{*}{ Age } & Up to 30 & 48.8 \\
\hline & $31-40$ & 31.5 \\
\hline & $41-50$ & 15.3 \\
\hline & 51 plus & 4.4 \\
\hline \multirow[t]{4}{*}{ Education } & Below secondary school & 3.7 \\
\hline & Secondary school and above & 24.7 \\
\hline & University degree & 34 \\
\hline & Above degree & 37.7 \\
\hline \multirow[t]{4}{*}{ Income } & Less than $£ 10000$ & 30.5 \\
\hline & Over $£ 10000-£ 20000$ & 35.6 \\
\hline & Over $£ 20000-£ 35000$ & 22.5 \\
\hline & Over $£ 35000$ & 11.3 \\
\hline \multirow[t]{2}{*}{ Marital status } & Married & 51.7 \\
\hline & Single & 48.3 \\
\hline \multirow[t]{4}{*}{ Ethnic origin } & British & 9.1 \\
\hline & Arab & 35.7 \\
\hline & Asia & 40.9 \\
\hline & Other & 14.3 \\
\hline \multirow[t]{5}{*}{ Occupation } & Professional & 39.9 \\
\hline & Semi skilled & 14.4 \\
\hline & Managerial & 11.7 \\
\hline & Student & 23.4 \\
\hline & Not employed & 10.7 \\
\hline
\end{tabular}


Table 2 Service Quality Dimensions

\begin{tabular}{|c|c|c|c|c|c|}
\hline Items & $F 1$ & $F 2$ & F3 & F4 & $F 5$ \\
\hline Friendly employees & 0.739 & & & & \\
\hline Polite employees & 0.736 & & & & \\
\hline Helpful employees & 0.721 & & & & \\
\hline Knowledgeable employees & 0.715 & & & & \\
\hline Employees give you individual attention & 0.662 & & & & \\
\hline Speed of transactions & 0.633 & & & & \\
\hline Bank resolves the problem quickly & 0.615 & & & & \\
\hline Efficient transactions & 0.602 & & & & \\
\hline Short waiting time in bank & 0.534 & & & & \\
\hline Confidence in bank's Shariah advisors & & 0.718 & & & \\
\hline Bank runs according to Islamic law & & 0.716 & & & \\
\hline Confidentiality of customer information & & 0.706 & & & \\
\hline Secure banking & & 0.662 & & & \\
\hline Accurate bank statement & & 0.620 & & & \\
\hline Confidence in bank's management & & 0.617 & & & \\
\hline Safe from political action & & 0.568 & & & \\
\hline Wide range of Islamic products & & 0.549 & & & \\
\hline Clear communication & & 0.542 & & & \\
\hline Easy bank to deal with & & 0.484 & & & \\
\hline Bank reputation & & 0.466 & & & \\
\hline Female staff wear hijab & & & 0.865 & & \\
\hline Bank has a prayer room & & & 0.807 & & \\
\hline Closing for Friday prayer time & & & 0.787 & & \\
\hline Separate department for ladies & & & 0.725 & & \\
\hline Bank has Islamic appearance & & & 0.658 & & \\
\hline Number of cash machine available & & & & 0.715 & \\
\hline Convenient opening hours & & & & 0.710 & \\
\hline $\begin{array}{l}\text { Wide range of Islamic services (eg } \\
\text { financial advisor) }\end{array}$ & & & & 0.614 & \\
\hline Low services charge & & & & 0.607 & \\
\hline Convenient bank location & & & & 0.586 & \\
\hline Bank size & & & & & 0.804 \\
\hline Well known bank & & & & & 0.721 \\
\hline Bank's building has Islamic architecture & & & & & 0.694 \\
\hline Modern looking equipment & & & & & 0.639 \\
\hline
\end{tabular}


Table 3: Importance for Islamic and non-Islamic bank account holders

\begin{tabular}{|c|c|c|c|c|c|}
\hline \multirow[b]{2}{*}{ Items } & \multirow[b]{2}{*}{$\begin{array}{l}\text { Asymp. } \\
\text { Sig }\end{array}$} & \multicolumn{2}{|c|}{$\begin{array}{c}\text { Islamic bank account } \\
\text { holders }\end{array}$} & \multicolumn{2}{|c|}{$\begin{array}{c}\text { Non-Islamic bank account } \\
\text { holders }\end{array}$} \\
\hline & & Mean rank & Median & Mean rank & Median \\
\hline $\begin{array}{l}\text { Secure } \\
\text { banking }\end{array}$ & .001 & 118.97 & 5.00 & 147.26 & 5.00 \\
\hline $\begin{array}{l}\text { Helpful } \\
\text { employees }\end{array}$ & .005 & 122.77 & 4.00 & 148.48 & 5.00 \\
\hline $\begin{array}{l}\text { Safe } \\
\text { from political } \\
\text { action }\end{array}$ & .010 & 125.73 & 4.00 & 149.02 & 5.00 \\
\hline $\begin{array}{l}\text { Bank } \\
\text { resolving } \\
\text { problems } \\
\text { quickly }\end{array}$ & .012 & 127.79 & 4.00 & 151.19 & 5.00 \\
\hline $\begin{array}{l}\text { Low service } \\
\text { charges }\end{array}$ & .014 & 116.47 & 4.00 & 139.55 & 4.00 \\
\hline $\begin{array}{l}\text { Convenient } \\
\text { bank location }\end{array}$ & .023 & 128.56 & 4.00 & 150.10 & 5.00 \\
\hline $\begin{array}{l}\text { Convenient } \\
\text { opening hours }\end{array}$ & .027 & 125.47 & 4.00 & 146.44 & 4.00 \\
\hline $\begin{array}{l}\text { Friendly } \\
\text { employees }\end{array}$ & .030 & 129.25 & 4.00 & 149.55 & 4.00 \\
\hline $\begin{array}{l}\text { Confidence } \\
\text { in bank's } \\
\text { management }\end{array}$ & .032 & 128.84 & 4.00 & 148.34 & 5.00 \\
\hline $\begin{array}{l}\text { Bank } \\
\text { reputation }\end{array}$ & 0.39 & 125.83 & 4.00 & 145.23 & 4.50 \\
\hline $\begin{array}{l}\text { Polite } \\
\text { employees }\end{array}$ & .049 & 130.58 & 4.00 & 148.83 & 5.00 \\
\hline $\begin{array}{l}\text { Confidentiality } \\
\text { of } \\
\text { customer } \\
\text { information }\end{array}$ & .050 & 132.35 & 5.00 & 147.29 & 5.00 \\
\hline
\end{tabular}

